\title{
RUSSIA AS A TARGET DOMAIN IN AMERICAN, BRITISH AND CANADIAN POLITICAL DISCOURSES
}

\author{
O.A. Solopova', o-solopova@bk.ru \\ M.Yu. Ilyushkina ${ }^{2}$, ilyushkina_maria@mail.ru \\ ${ }^{1}$ South Ural State University, Chelyabinsk, Russian Federation \\ ${ }^{2}$ Ural Federal University, Ekaterinburg, Russian Federation
}

\begin{abstract}
This article presents a fragment of the study of political metaphors involved in shaping the image of Russia in English mass media. Using corpus technologies, an array of material was analyzed in an original way from the NOW English-language corpus (electronic versions of articles from American, British and Canadian newspapers and magazines for June 12, 2016) - dominant metaphorical models, their most frequent frames, the models' discursive characteristics, and pragmatic potential were revealed. The significance of the work is the use of corpus linguistics methods to study political metaphors, which greatly enriches the set of methods for studying political metaphors, increasing the representativeness and objectivity of the results obtained.
\end{abstract}

Keywords: corpus linguistics, NOW corpus, methods of corpus analysis, cognitive-discursive approach, metaphor, political discourse, image of Russia.

\section{Introduction}

In the process of studying the formation of a country's image in the minds of its citizens and representatives of other states, special attention is paid to the use of political metaphor, which is of relevance to ongoing study. Metaphors play a central role in discourse, since they formulate the structure of political conceptualization and argumentation (Musolff, 2004). The study of the political metaphorics makes it possible to systematize the material and describe the corresponding section of the metaphorical political picture of the world, taking into account the sociopolitical situation, the characteristics of political realities, the political features of the phenomenon under consideration, and other discursive factors. Researchers note that the metaphor, due to its flexibility and multifacetedness, proves to be a very productive tool of political language in the ever-changing reality.

In accordance with the concepts of the modern cognitive linguistics, metaphorical modeling is a means reflecting national, social and personal selfawareness of comprehending, collating, presenting and evaluating a fragment of reality with the help of scenarios, frames and slots referring to a completely different conceptual domain. In addition, metaphor is a powerful means of manipulating social consciousness. It is metaphor that makes it possible to create a bright, attractive or repulsive, but definitely memorable, image in the recipient. Metaphors aimed at modeling the image of Russia are subject to a large number of studies (Budaev, Chudinov, 2008; Chudinov, 2003; Deignan, 2005; Graber, 1981; Lakoff, Johnson, 2003; Solopova, 2016; Zinken, 2007).

Linguists note that "the image of Russia is a symbolic model that determines the ideas about the state through the concepts and judgments accessible to the ordinary consciousness and does not always cor- respond to objective indicators of national development" (Budaev, Chudinov, 2008). Most works are completed through the cognitive-discursive approach, taking into account the cognitive metaphor theory (Lakoff, Johnson, 2003) and the theory of metaphorical modeling (Chudinov, 2003). In this article, an attempt has been made for the first time to investigate the political metaphorics using computer programs for processing, analyzing and describing metaphorical units: the metaphor becomes an object of the corpus linguistics, which determines the novelty of the research being conducted.

\section{Methods}

The diversity of scientific schools, principles and methods of studying metaphorical modeling naturally leads to the fact that metaphor is considered in various aspects using different methods and description algorithms. In the process of the present study, observation, analysis, synthesis, and inductive and deductive methods are used as general scientific methods. The main methods are as follows:

1. Corpus analysis, which reveals real word usage in the natural language environment and helps analyze the whole array of texts from which metaphors are selected. The corpus approach enables the quick aquisition of a large sample of material, analysis of the aspects of using language units, and drawing of conclusions based on specific statistics. As E. Deignan notes, "the corpus linguistics largely supports the cognitive theory of metaphor, but the corpuscular data question the details of the theory" (Deignan, 2005). The advantages of this method are its representativeness, economy and objectivity. The methods of corpus analysis of a text make it possible to increase the effectiveness of research activity due to its automated system of selection, processing and results output. The 


\section{Политический дискурс}

use of corpus analysis methods by a linguist makes it possible to calculate and compile statistics that confirm or disprove research hypotheses, and to justify the conclusions based on accurate, empirical data. Nevertheless, it should be noted that, like all computer programs, corpus technologies cannot independently identify, generalize, analyze, or interpret the received metaphors. For this reason, the researcher himself must extract metaphorical contexts from the corpus, or part of the corpus, manually. There are special methods to facilitate the extraction of certain metaphorical expressions such as the method of continuous sampling, the method of searching for lexical units from the source sphere, and others. Since the main role in the corpus linguistics is fulfilled by the word, the search for necessary data in the corpus is carried out by word forms or word combinations. Due to this, the process of searching for metaphorical units with a certain target sphere is simplified.

2. Cognitive-discursive analysis, which allows for the combination of different views of the research, making it possible to identify the entire complex of features of the construction and interpretation of the image of Russia due to the discursive factors and linguocultural specifics. The cognitive-discursive paradigm synthesizes the ideas "language as cognition" and "language use as a discourse". The significance of the cognitive-discursive approach lies in the ability to study linguistic phenomena at the intersection of two perspectives: cognitive and discursive. This approach is not only focused on the explication of the cognitive mechanism of the discourse, but also takes into account the sociohistorical and linguocultural factors.

3. Method of metaphorical modeling, which makes it possible to demonstrate the specificity of the dominant metaphorical models. Description of the metaphorical model includes the following aspects: evaluation of the model's productivity in modeling the image of Russia; description of the model's frame structure (selection of the most frequent frames and their characteristics, indicating the component that connects the primary and metaphorical meanings of the units covered by the model, definition of features that these spheres closer together metaphorically); discursive characteristic of the model, that is, the identification of conceptual vectors typical for the respective metaphors, leading emotive characteristics, their interrelation with the existing political situation, specific political events, political views, intentions of communication subjects, etc.; characteristics of the pragmatic potential of the model, that is, the ability of metaphors to model negative and positive images.

4. Descriptive method, implemented by means of the interpretative method, a partial use of the method of component and contextual analysis.

The use of these methods makes it possible to comprehensively analyze the metaphorical representation of the image of Russia in English-language media, since considering the metaphor in isolation, within the cognitive approach, sociocultural or any other, the re- searcher receives reliable but disparate data: such an analysis is partial, incomplete and inaccurate, as it is the interaction of cognitive features and discursive factors caused by the historical moment of the development of society, with the support of the methods of the corpus analysis, that gives a complete objective picture.

\section{Material}

For the proponent of corpus linguistics, the choice of the corpus for research is of great importance. The methodological procedure for choosing a corpus usually goes through several stages. To begin with, the researcher must decide what he will consider a corpus to be. C. Meyer (Meyer, 2004) distinguishes two basic approaches to the definition of this concept. In the first case, the corpus is any set of texts, in the second - a relatively large set of natural texts, which are stored in a ready-for-computer-processing form. Further, the researcher needs to determine whether he needs a specialized or non-specialized (general language), fragmentary or full-text, open (replenished) or closed corpus.

The material of this work is collected on the basis of sampling from a fairly large set of natural texts of the full-text open NOW corpus and is presented with electronic versions of articles from American, British and Canadian newspapers and magazines dated June 12, 2016 (New York Post, Arkansas Online NBCNews.com, National Post, Voice of America, Deutsche Welle, Quad City Times, Gothamist, TheChronicleHerald.ca, CanIndiaNews, Stockhouse, theifp.ca, National Post, attitude.co.uk, Daily Star, Daily Star, Evening Standard, SkySports, Scotsman, BT Sport, Express.co.uk, Exeter Express and Echo, The Chronicle Journal, MetroNews Canada, BBC News, The Independent, etc.) (Fig. 1). The contexts from American publications used to illustrate the provisions are given in the text with the mark "US"; the contexts from the British editions are given in the text with the mark "GB", and from Canadian - "CA".

The sample size is represented by 180 metaphorical units, the target areas of which are "Russia", "Russian", "Russians" and "Putin" (Fig. 2). Let us note that the image of the Russian President V.V. Putin is often synonymous with Russia, a personified symbol of the whole state.

In Russia, June 12 is an important state holiday the Day of Independence or the Day of Adoption of Declaration on the State Sovereignty of Russia. In addition, state significance is attached to this since on this day, for the first time in the country's history, open presidential elections were held across the nation. As a result of the elections in 1991, the country chose the first President - B.N. Yeltsin. On February 1, 2002, from the Labor Code of the Russian Federation coming into force, June 12 officially became known as the Day of Russia. Despite the fact that the Independence Day of Russia is a relatively "young" state holiday, for its people it is considered a symbol of national unity and the result of many years of work for the good of the Motherland. In this article, an attempt 


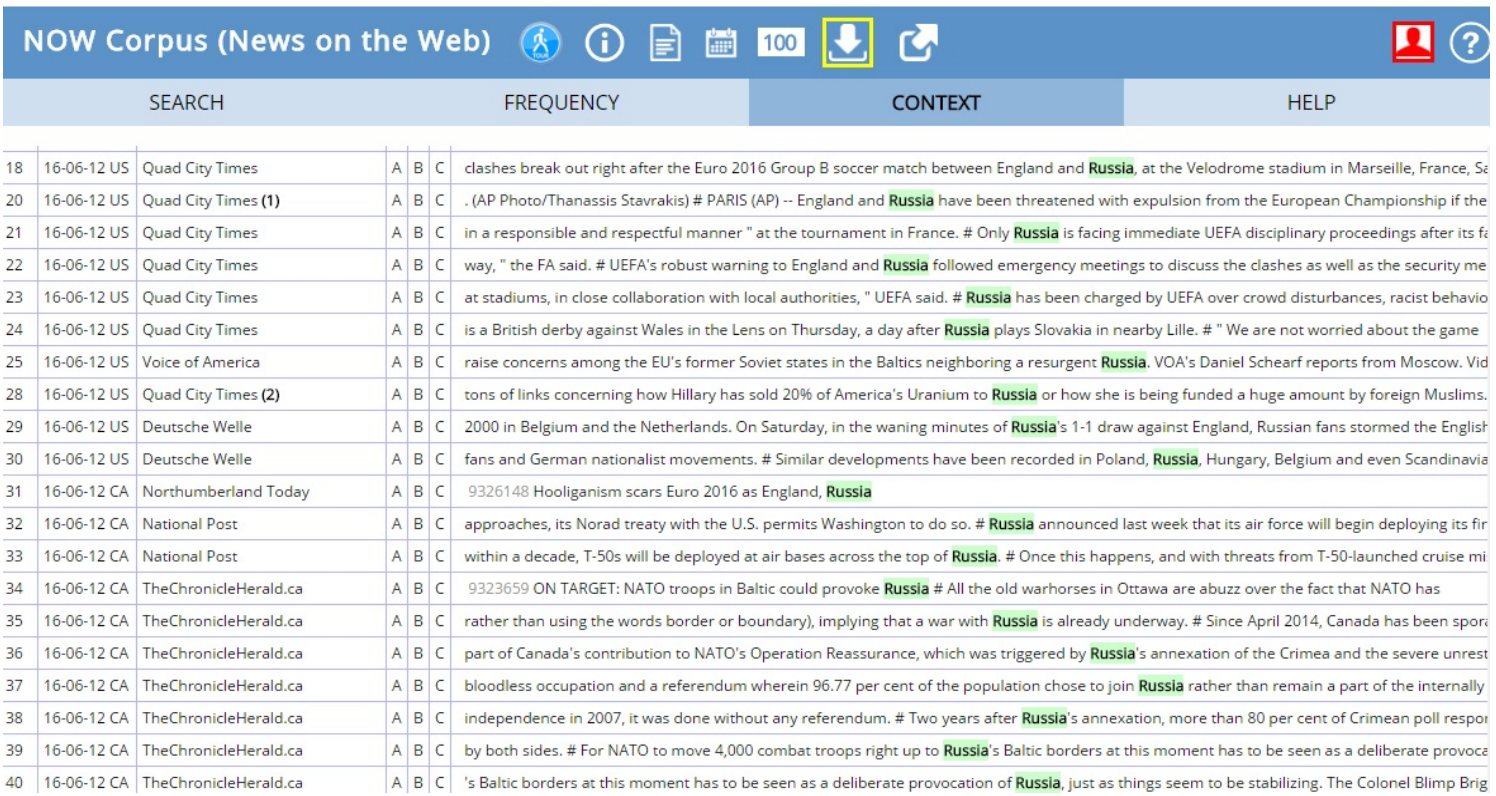

Fig. 1. Output of data

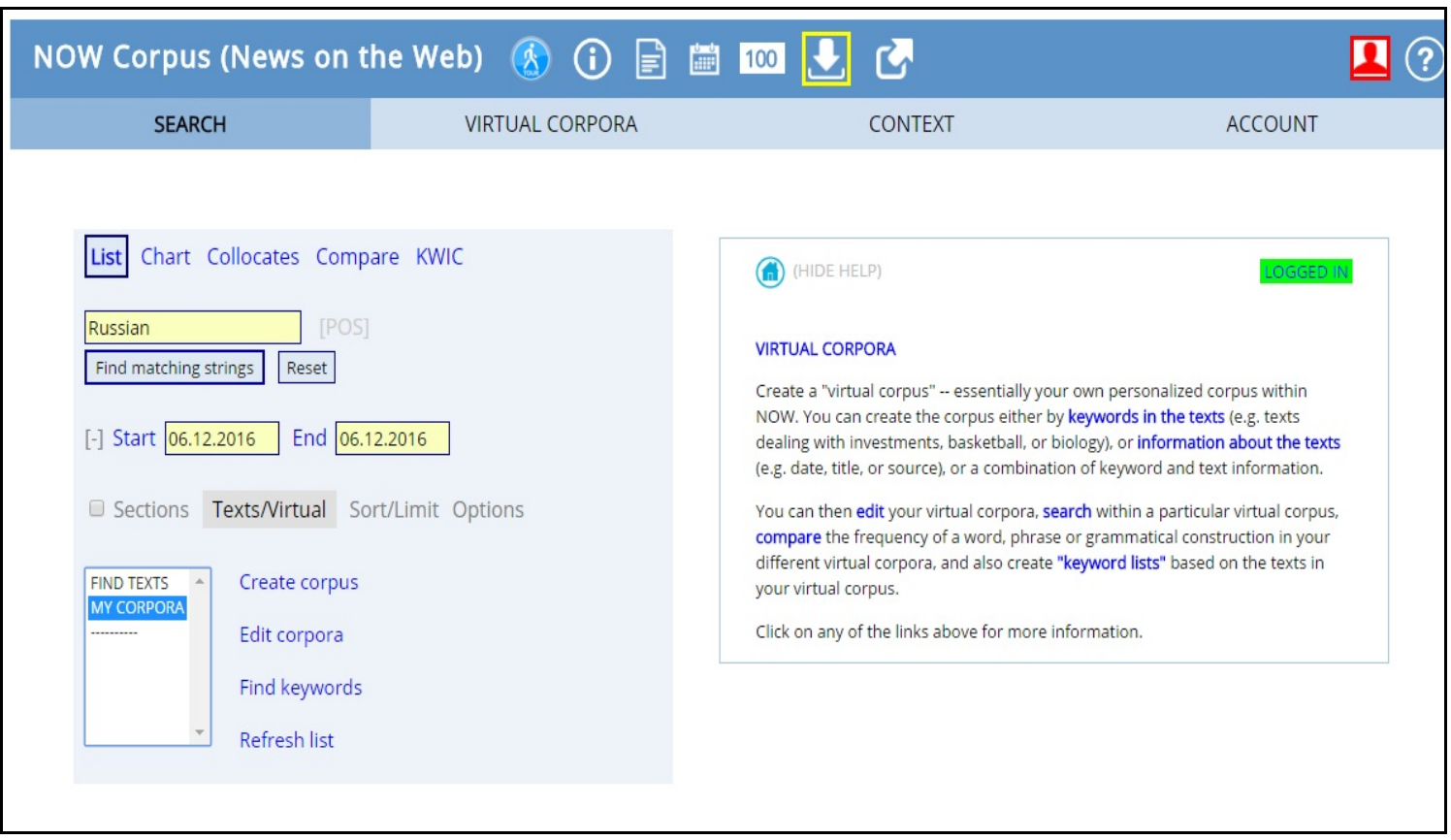

Fig. 2. Fragment of searching for data on the wordform in the NOW corpus

is made to investigate how the choice of a significant day for Russia affects the modeling of the image of the country in the English-language media. The hypothesis of the research being conducted is that the chronographic scope of the work and the choice of the Independence Day, a nationally significant holiday of Russia, influence the activity of metaphorical units, the choice of metaphorical models in which the image of Russia is represented, the meanings that are extrapolated when applying each of the images, and the demand for metaphors with a negative/positive pragmatic potential.

\section{Data Analysis and Results}

The conducted analysis of the corpus of texts shows that 7 models are involved in the representation of Russia's image (Fig. 3). The military images are dominant $(51 \%)$. Next, the criminal metaphor $(38 \%)$, the metaphor of "family relations" $(8 \%)$, and other metaphorical models $(3 \%)$ follow in order of decreasing frequency. In covering situations related to Russia's participation, a group of metaphors take the leading place in foreign media: "Russian policy is war" (Fig. 4). 


\section{Политический дискурс}

In most cases, for the representation of the image of Russia, metaphorical units denoting military operations and operations, or warfare tactics are used, such as «war», «rebellion», «Putin's annexation», «bloodless occupation», "a strategic necessity», "to storm», "cruel blow», "racist behavior», "full-frontal attack»: «NATO's Operation Reassurance, which was triggered by Russia's annexation of the Crimea» (The Chronicle Herald, June 12, 2016), (CA). The use of military metaphors with a pronounced negative pragmatic potential in the discourse about Russia and the dominance of a model (its separate frames and slots) with the conceptual vectors of cruelty, aggres- siveness, and rivalry are caused by the desire of foreign media to present the policy of the Russian Federation (both external and internal) as a "war against everyone". Russia is "an aggressor seeking to seize the world from considerations of its own strategic security. «Putin's land grab in the Crimea was something of a strategic necessity...» (The Chronicle Herald, June 12, 2016), (CA).

The image of Russia is modeled in a negative way, the military metaphoric is accompanied by frequent repetition and variation of lexemes with the meaning of "aggression": «bloody battles», «Russians'storms», "army of Russians», "Russia's attack», etc.

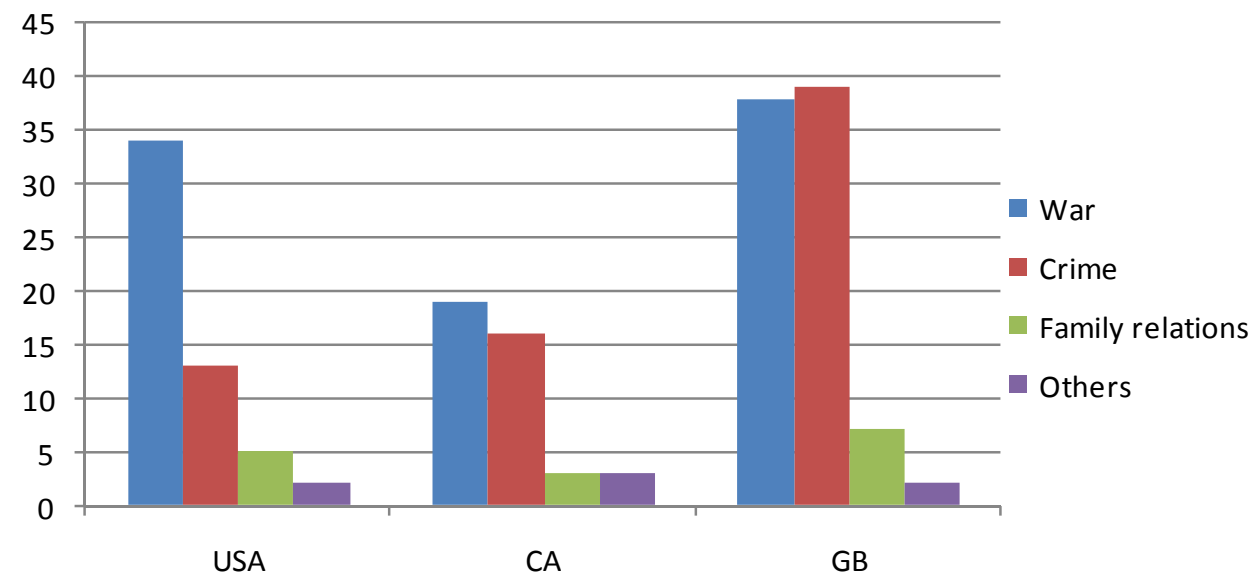

Fig. 3. Metaphorical models representing the image of Russia

\section{Russia's enemy No. 1? Mystery campaign smears Obama}

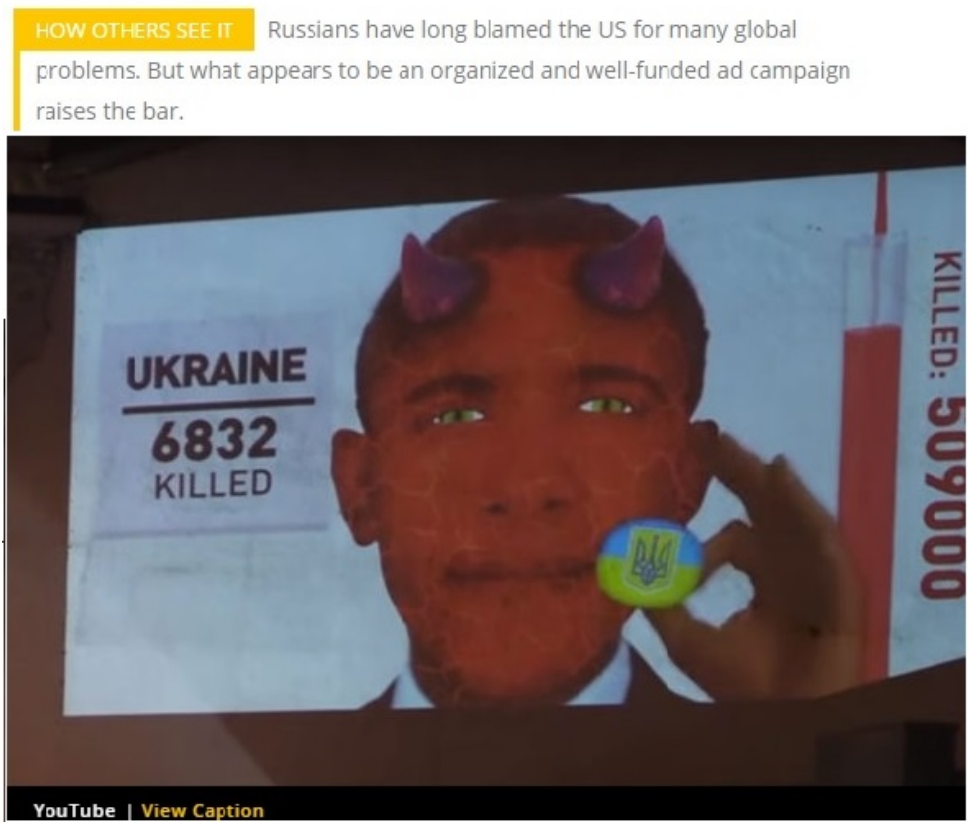

Fig. 4. Fragment of the article from the electronic magazine of The Cristian Science Monitor (CA) 
The frame structure of the model "Russian policy is war" is represented as follows:

"Allies and Enemies" frame

This frame includes metaphorical units reflecting the external-non-political relationships of political actors. The object of metaphorization is countries that are partners or opponents of Russia in the international arena. Especially active are the direct names "enemy, adversary, foe", "ally, partner, friend" with the unconditional dominance of words that model the image of an enemy: «...speculation about conservative attempts to make China and Russia out to be foreign enemies» (The American Prospect, June 12, 2016), (US). The militaristic metaphorics aimed at broadcasting antagonistic relations between countries bear a negative emotional charge. The metaphors of the model represent the current situation as problematic, volatile, poorly projected, with probable "stormy", dangerous consequences for all countries participating in events for which Russia is often the catalyst.

"Arms" frame

This frame enables the identification of typical metaphorical attitudes of the English-language media towards the political actions in Russia and includes names of weapons aimed at destroying political opponents and achieving the main goal - Russia's domination in the world community. "...chose racism as his weapon, but his aim is exactly the same» (Westminster News Online, June 12, 2016), (GB). Such metaphors form an image of a dangerous, menacing policy of the Russian Federation and its president and impose negative pragmatic meanings on the impossibility of a fruitful and peaceful solution of the geopolitical problems and disagreements involving Russia.

"Military Actions" frame

The denotative sphere of metaphor application covers the activities of Russia in the international arena. Russia, in the opinion of the English-language media, is a country that strives to resolve issues from the position of strength: Russia should be threatened with expulsion over their "full-frontal attack» (Telegraph.co.uk, June 12, 2016), (GB). The activation of the metaphors of this frame, their diversity, allow for the identification of typical metaphorical notions of Russia as a dangerous country that does not want to peacefully settle emerging conflicts, using sophisticated strategies and tactics of warfare that are known to it.

"War and its variants" frame

The metaphorical units that represent Russia's actions in the international arena as different types of war are aimed at forming an image of the state that does not aim to solve problems with "peaceful" methods but is focused on active participation in geopolitical battles, posing a threat to the world community: "...war with Russia is already underway (The Chronicle Herald, June 12, 2016), (CA). Frequent repetition and variations of lexemes with the meaning of "aggression" in the English-language corpus of political texts creates a lasting picture of the automated accep- tability of information: the high intensity of emotions embedded in the connotative aspects of military metaphors provokes sustained reactions of protest, fear, rejection of Russia and its policies.

In addition to the images of war in the corpus of American, British, and Canadian texts, the share of criminal metaphors $(38 \%)$ is large, with the conceptual vector of deviation from the natural order of things. The criminal metaphorics can create a picture in the recipient where the country itself, society, and the Russian authorities are presented as a criminal community in which crime is one of the main means of achieving the goal. In the center of emotional states created by the criminal metaphor there is the denial of the established corrupt system of power, resentment, and an awareness of the need to change the course of development of the country.

The frame structure of the model "Russian policy is criminal" is presented as follows:

"Criminals" frame

The most negative pragmatic potential is explicated by the metaphorical names of the frame "Criminals". In the center of emotional states, the formation of which is directed by the conceptual vector of the criminal metaphor, there is a denial of the current system of power in Russia, which makes the representation of the president of this and future Russia as the main criminal: Let us not mince words: Vladimir Putin is a delusional thug (The New York Times, June 12, 2016), (US). The units of this model are also used to characterize the country as a whole, modeling the idea of the criminal structure of the internal political system of the country, which, on the one hand, poses a threat to the development, functioning and existence of the country itself. On the other hand, it is a source of danger for the international community: ... an even vaster, paranoid, trigger-happy hooligan of a country: Mother Russia (The Times, June 12, 2016), (GB); Russia is a "mafia state» (The Guardian, June 12, 2016), (GB). Obviously, this type of metaphorical usage carries a negative emotional connotation.

"Victims of crime" frame

As it is known, the actions of "criminals" cannot do without victims: "...she (Ukraine) is nothing more than the victim of Putin's latest version of a show trial» (Washington Times, June 12, 2016), (USA); "Whether she was falling into the Russia's trap..." (The Guardian, June 12, 2016), (GB). An attitude towards other countries as victims of the disastrous policy of the state is cultivated in the process of modeling the image of Russia. The metaphorical nominations of this frame, in which the vectors of danger, aggressiveness and anxiety characteristic of the modern Englishlanguage corpus of political texts are most clearly manifested, are used to create the image of Russia's destructive policy and the need to prevent, suppress, and disrupt its unfair foreign policy maneuvers is modeled. The use of units of the source sphere serves, as a whole, to discredit the Russian political and economic system, its domestic and foreign policy, and as a sharp 


\section{Политический дискурс}

contrast between "us" and "them", which is actively supported by the military metaphorics on demand in the modern corpus of English-language texts.

"Criminal activity" frame

For the metaphors of this frame, there is typically a predominance of negative pragmatic potential in their constituent contexts: Russia is a country where lawlessness reigns, permeating its history, organically intertwines in the modern life of the country, and rushes into the future, fastening them into a single lawless whole: «Because of Russia's depredations against it» (Bloomberg View, June 12, 2016), (GB); «Criminal elements enjoy $a$ krysha $\langle\ldots>$ that runs through the police...» (The Guardian, June 12, 2016), (GB). Conceptually, the metaphorical units of the source sphere expose an extreme degree of social danger, pronounced crime, producing repulsive images of "terrible" criminal Russia. A significant portion of criminal metaphorical denominations with negative appraisal verbalizes the notion of deformations of the country's socio-political structure.

The next most frequent metaphorical model, in which Russia's image in foreign media is represented, is the "Russia is a family" model (8\%). In the American, British and Canadian media, members of the "Russian family" are Russian citizens, leaders and peoples of foreign countries who support the Russian political course: «Russia's <...> Clan Wants Its Old Country Back" (The Times, June 12, 2016), (GB); «Putin's band of brothers»(The Sunday Times, June 12, 2016), (GB). Most often, the brothers and sisters of Russia are the East Slavic states (with the exception of Ukraine) and the countries of the AsiaPacific region (mainly China). European countries and the United States are represented as states with which Russia "enters into a fictitious marriage", pursuing its own mercantile goals.

The frame structure of the model "Russian poli-

cy is family relations" is represented as follows:

"Kinship" frame

The traditional metaphorical representation of Russia as a loving mother, unable to betray her child the Russian people, the father-ruler model relations between Russia and its citizens as conjugal, and family relations in a patriarchal family whose members feel not only a kinship between themselves, but also a spiritual affection for one another: «Russians are worried about Putin's absence as kids would be if their father had wandered off somewhere» (Bloomberg View, June 12, 2016), (GB). Within the metaphor of kinship, relations between Russia, its ruler, and the people are conceptually presented as emotional and spiritual affection for each other.

"Matrimonial relations" frame

In the framework of the metaphor of marriage, the modeling of Russia's relations with other countries on controversial foreign policy issues is linked to the concepts of fictitious marriage, treason, divorce: «It's a marriage based on needs: Russia's to break out of the isolation...» (Foreign Policy, June 12, 2016), (USA); "Ukraine buys into a reluctant marriage with the Russians» (Washington Times, June 12, 2016), (USA). Metaphors create expressively colored, textrich overtones. In the above metaphorical usage, a negative appraisal develops, connected with the connotations of fraud, self-interest, and immorality, as a result the necessary perception of the event described and an acute negative attitude to the main "character" of the drama is formed by the addressee.

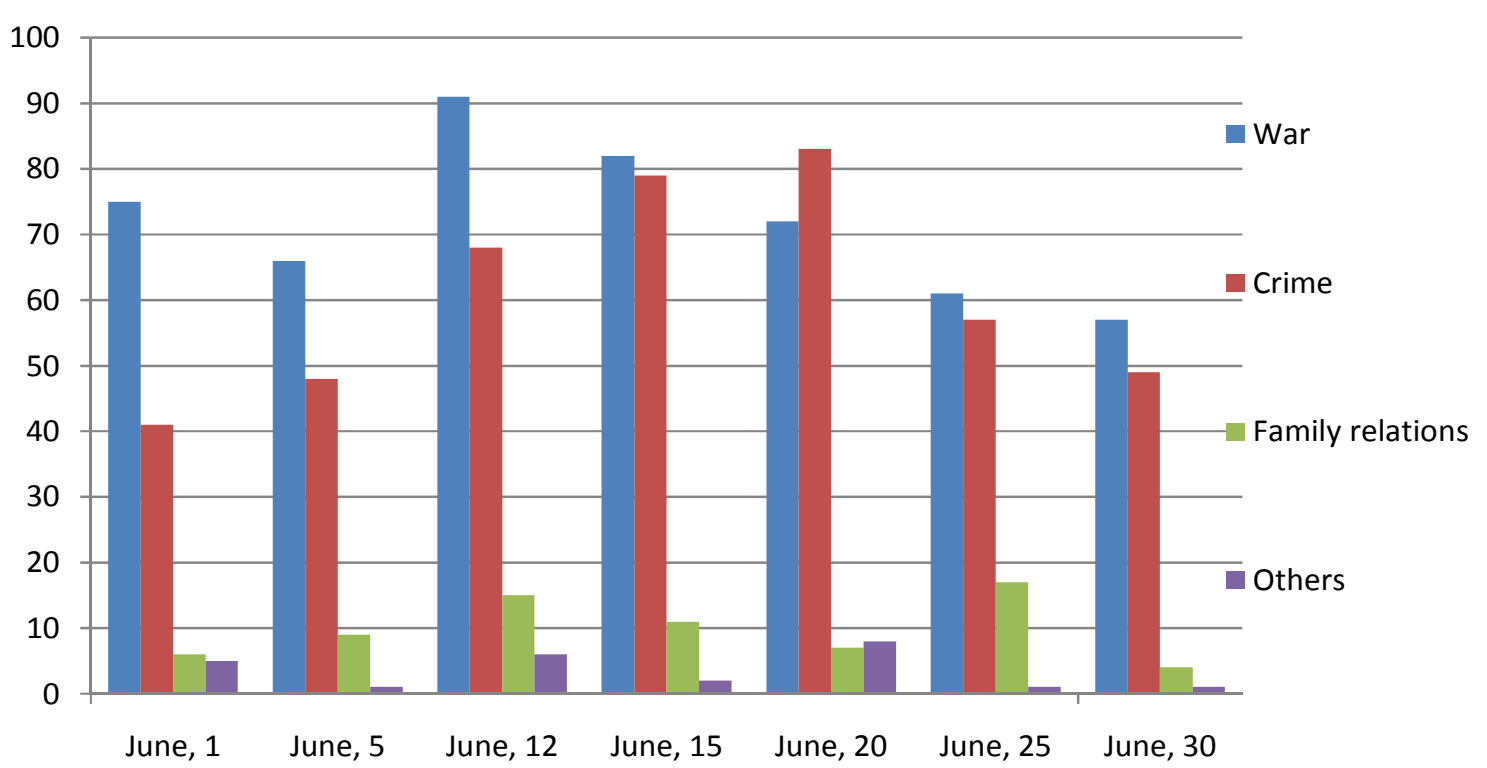

Fig. 5. Statistics of the use of metaphors with the target areas "Russia", "Russian", "Russians" and "Putin" for randomly selected dates (June 2016) 


\section{Conclusion}

The hypothesis advanced at the beginning of the study was partially confirmed (Fig. 5). On the one hand, the amount of metaphorical usage involved in modeling Russia's image on June 12, 2016 is higher than in other dates (June 2016) randomly selected for comparison. On the other hand, during comparison, general tendencies in the representation of Russia's image are fixed: statistics of usage (with target areas "Russia", "Russian" and "Russians", "Putin") for randomly selected days of one month showed that but for an insignificant exclusion (on June 20), the selected metaphorical models are equally distributed on the frequency scale.

The metaphorical units of the metaphorical models dominant for the corpus of the English-language texts form a pejorative image of an aggressor country, whose foreign policy is unpredictable, dangerous and destructive. The metaphors of the considered source spheres increase the effectiveness of the speech impact on the consciousness of the addressee and are intensively used in the discourse on Russia to manipulate the public consciousness, provoking the addressee's "necessary" reaction, asserting the existing stereotypes, and creating new sociopolitical myths. The media intentionally use certain cognitive settings to form an image of Russia in the recipient's mind, which corresponds to their goals, creating a "virtual reality in the addressees, where their own empirical practice is eliminated through proposed cognitive schemes" (Graber, 1981: 198).

The theoretical significance of the research is the use of corpus technologies for the study of political metaphorics, which greatly enriches a set of methods for studying political metaphors and raises the representativeness and objectivity of the results obtained. The results of the research can be used in elective higher school courses "Modern Political Linguistics", "Political Metaphor", and "Corpus linguistics".

\section{References}

1. Budaev E.V., Chudinov A.P. Metaphor in political communication Moscow: Flint: Science, 2008.

2. Chudinov A.P. Metaphorical mosaic in modern political communication. Ekaterinburg: Publishing house Ural. State. Ped. Univ., 2003.

3. Deignan A. Metaphor and Corpus Linguistics. Amsterdam; Philadelphia: John Benjamins, 2005.

4. Graber D. Political Languages. In Handbook of Political Communication. Beverly Hills, London: Sage Publications, 1981, pp. 195-224.

5. Lakoff G., Johnson M. Metaphors we Live by. Chicago: University of Chicago Press, 2003.

6. Meyer Ch.F. English Corpus Linguistics: An Introduction. Cambridge: Cambridge University Press, 2004.

7. Musolff A. Metaphor and Political Discourse. Analogical Reasoning in Debates about Europe. New York: Palgrave Macmillan, 2004.

8. Solopova O.A. Lingvopolitical prognostics: a comparative study of models of the future of Russia in the political discourses of Russia, the United States and Britain of the XIX $X^{\text {th }}(1855-1881)$ and XXI $I^{\text {t }}$ centuries (2000-2014). Ekaterinburg, 2016.

9. Zinken J. Discourse metaphors: The link between figurative language and habitual analogies. Cognitive Linguistics, 2007, 18 (3), pp. 445-466.

Olga A. Solopova, doctoral degree in philology, professor, Linguistics and Translation Chair, South Ural State University (Chelyabinsk), o-solopova@bk.ru

Maria Yu. Ilyushkina, candidate degree in philology, associate professor, Department of Linguistics and Professional Communication in Foreign Languages, Ural Federal University, Lenin Street (Yekaterinburg), ilyushkina_maria@mail.ru

Received 27 June 2017

Удк 81-144 + 81-112

DOI: 10.14529/ling170306

\title{
СФЕРА-МИШЕНЬ «РОССИЯ» В АМЕРИКАНСКОМ, БРИТАНСКОМ И КАНАДСКОМ ПОЛИТИЧЕСКИХ ДИСКУРСАХ
}

\author{
О.А. Солопова ${ }^{1}$, М.Ю. Илюшкина ${ }^{2}$ \\ ${ }_{1}$ Южно-Уральский государственный университет, г. Челябинск \\ 2 Уральский федеральный университет им. первого Президента России Б.Н. Ельцина, \\ г. Екатеринбург
}

В настоящей статье представлен фрагмент исследования политических метафор, задействованных в формировании образа России в американском, британском и канадском политических дискурсах. В оригинальном ключе с привлечением корпусных технологий проанализирован массив материала из англоязычного корпуса NOW (электронные варианты статей из американских, 


\section{Политический дискурс}

британских и канадских газет и журналов за 12 июня 2016), выявлены доминантные метафорические модели, их наиболее частотные фреймы, дискурсивная характеристика моделей, прагматический потенциал. Значимость работы заключается в привлечении методов корпусной лингвистики для исследования политической метафорики, что существенно обогащает набор приемов изучения политических метафор, повышая репрезентативность и объективность полученных результатов.

Ключевые слова: корпусная лингвистика, корпус NOW, методы корпусного анализа, когнитивно-дискурсивный подход, метафора, политический дискурс, образ России.

\section{Литература}

1. Будаев, Э.В. Метафора в политической коммуникаичи: монография / Э.В. Будаев, А.П. Чудинов. М.: Флинта : Наука, 2008. - 248 c.

2. Чудинов, А.П. Метафорическая мозаика в современной политической коммуникаџии / А.П. Чудинов. - Екатеринбург: Изд-во УрГПУ, 2003. - 248 с.

3. Deignan, A. Metaphor and Corpus Linguistics / A. Deignan. - Amsterdam; Philadelphia: John Benjamins, 2005 .

4. Graber, D. Political Languages / D. Graber // In Handbook of Political Communication. - Beverly Hills, London: Sage Publications. 1981. - P. 195-224.

5. Lakoff, G. Metaphors we Live by / G. Lakoff, M. Johnson. - Chicago: University of Chicago Press, 2003.

6. Meyer, Ch.F. English Corpus Linguistics: An Introduction / Ch.F. Meyer. - Cambridge: Cambridge University Press, 2004.

7. Musolff, A. Metaphor and Political Discourse. Analogical Reasoning in Debates about Europe / A. Musolff. - New York: Palgrave Macmillan, 2004.

8. Солопова, О.А. Лингвополитическая прогностика: сопоставительное исследование моделей будущего России в политических дискурсах России, США и Великобритании XIX в. (1855-1881) и XXI в. (20002014): дис. ... д-ра филол. наук / О.А. Солопова. - Екатеринбург, 2016. - 606 с.

9. Zinken, J. Discourse metaphors: The link between figurative language and habitual analogies /J. Zinken, // Cognitive Linguistics. - 2007. - 18 (3). - P. 445-466.

Солопова Ольга Александровна, доктор филологических наук, профессор кафедры лингвистики и перевода Института Лингвистики и межкультурных коммуникаций, Южно-Уральский государственный университет (Челябинск), o-solopova@bk.ru

Илюшкина Мария Юрьевна, кандидат филологических наук, доцент кафедры лингвистики и профессиональной коммуникации на иностранных языках, Уральский федеральный университет им. первого Президента России Б.Н. Ельцина (Екатеринбург), ilyushkina_maria@mail.ru

Поступила в редакцию 27 июня 20172.

\section{ОБРАЗЕЦ ЦИТИРОВАНИЯ}

Solopova, O.A. Russia as a Target Domain in American, British and Canadian Political Discourses / O.A. Solopova , M.Yu. Ilyushkina // Вестник ЮУрГУ. Серия «Лингвистика». - 2017. - Т. 14, № 3. - С. 41-48. DOI: $10.14529 /$ ling 170306

\section{FOR CITATION}

Solopova O.A., Ilyushkina M.Yu. Russia as a Target Domain in American, British and Canadian Political Discourses. Bulletin of the South Ural State University. Ser. Linguistics. 2017, vol. 14, no. 3, pp. 41-48. DOI: $10.14529 /$ ling 170306 